\title{
Letitia E. Landon and Isabella Bird: Female Perspectives of Asia in the Victorian Text
}

\section{Sharifah Aishah Osman}

British representations of Asia became an increasingly common cultural and literary phenomenon in the nineteenth century, with works of fiction and non-fiction replete with various depictions of life in the East flooding the literary marketplace. With Romantic Orientalism firmly established as a literary trope, the exoticism of the East proved highly attractive as a source of inspiration for male poets such as Lord Byron, Robert Southey, and Thomas Moore, and many eagerly took up Byron's advice to "stick to the East [as] the public are orientalizing."1 British colonial expansion in countries like India, China and Malaya in the second half of the nineteenth century especially resulted in a rise in the number of female travellers and expatriates tapping into this lucrative market for Orientalist fiction and non-fiction, providing their own accounts of Eastern landscapes, cultures, and peoples that rivalled those of earlier predominantly male voices. This essay examines the depictions of Asia in the writings of two prominent Victorian female authors, the poet and short story writer, Letitia Elizabeth Landon (more popularly known as LEL), who published in the 1830s, and Isabella Bird, the famed explorer and first woman fellow of the Royal Geographical Society, who published from 1856 until 1901. My discussion will juxtapose Landon's portrayal of China and Malaya in two poems, namely "Macao" (1833) and "Pulo Penang" (1836) with Bird's accounts of China and Malaya in her travelogue The Golden Chersonese and the Way Thither (1883).

I argue that Landon's detached view of the Orient demonstrates how, for her, the East existed mostly as a conceptual, abstract space from which she chose to 
highlight the problems of women closer to home, including her own struggles as a professional writer, whereas Bird's perspective illustrates her role as an intrepid adventurer with a real interest in the places she visited and the peoples and cultures she observed. The essay also aims to show how the two women's personal lives not only influenced their contrasting literary styles but also their attitude towards the East. As a single, orphaned female author, vulnerable to "envy, malice and all uncharitableness" and "dependent on popularity," 2 Landon confined herself to her modest lodgings in London for most of her life, until she fled at the age of 32 with her new husband Capt. George McLean to West Africa, but where she died barely five months later. Bird, in contrast, shunned marriage until she turned fifty to travel the world with the blessings of a supportive father and a loving sister, continued to do so well into her 60s after the demise of her husband Dr. John Bishop, and regarded travel to foreign lands as the ultimate "escape from civilization"3--an enervating force that provided her with a freedom that she could never experience at home in polite English society as "Mrs. Bishop of Edinburgh." ${ }^{4}$ In short, the writings of both women reveal as much about the private and public struggles of the professional female author as they do about British perceptions of Asia in the nineteenth century.

\section{Landon's Asia: "Macao" and "Pulo Penang"}

Letitia Elizabeth Landon's literary career which ended with her tragic death in Cape Coast Castle, West Africa at the age of 36, illustrates the risks and obstacles that the single, professional woman writer faced in the nineteenth century. Landon's decision to live alone for most of her life in a rented attic room in London, where she wrote all her best-selling works and conducted her professional business until her marriage in June 1838 exposed her to much gossip, speculation, and resentment--a consequence of what she termed her 
"unprotected" status as an unmarried and orphaned woman who wrote for profit. Alluding to the malicious rumours that frequently circulated in the London salons about her link to men (both single and married), Landon declared resignedly in an 1837 letter to the biographer S.C. Hall that, "my life has convinced me that a public career must be a pitiful one for a woman. The envy and notoriety carry with them a bitterness which predominates over the praise."5 Indeed, Landon's semi-autobiographical poems like The Improvisatrice (1824) and A History of the Lyre (1828) not only reveal the insufficiency of fame in compensating for the lack of a fulfilling personal life but also emphasize how professional success serves only to inhibit a woman's achievement of true domestic happiness.

Despite having to endure various slights on her respectability, Landon went on to have a successful and prolific career as an author, a fact that has unfortunately been overshadowed by the sordid details surrounding her mysterious death barely five months after her marriage to Capt. John McLean, a colonial administrator. Much of Landon's popularity was derived from her association with the annuals or gift books that dominated the literary market from the mid-1820s to the mid-1840s, especially as contributor and editor to three of the most fashionable and financially successful, namely The Keepsake, Heath'sBook of Beauty, and Fisher's Drawing Room Scrap Book (which she edited exclusively from 1832 until her death in 1838). Aimed at a genteel and predominantly female readership, the annuals consisted of poems and stories provided by well-connected contributors and were frequently accompanied by illustrated plates or fine steel engravings of various beautiful young women, portraits of stately homes or exotic Eastern landscapes visited only by the affluent. Among some of these poems set in "exotic" locales, two that demonstrate Landon's portrayal of Asia are of particular interest, specifically "Macao" and "Pulo Penang," since they provide illuminating counter perspectives to Bird's representation of similar settings 
in her 1883 travelogue of Asia (or more specifically Malaya), The Golden Chersonese and the Way Thither.

In emphasizing the link between travel writing and colonialist discourse, Mary Louise Pratt notes how colonialism was generally perceived as a "masculine" project, the genre itself marked by "the rhetoric of discovery" and "a goal-oriented rhetoric of conquest and achievement," one transmitted through and dominated by the voice of the male narrator (148). In contrast, women travel writers, as Sara Mills argues, were regarded as "marginal" figures in the colonial discursive framework, their presence in the exotic places they visited often considered "eccentric, abnormal, even slightly ridiculous" and the veracity of their accounts "cast in doubt as exaggerated women's tales" (O'Callaghan 94). Mills explains the double standards with regards to the gendered perception of nineteenth-century travel writing in the following terms:

In the colonial context, British women were only allowed to figure as symbols of home and purity; women as active participants can barely be conceived of. This is because of social conventions for conceptualizing imperialism, which seem to be as much about constructing a masculine British identity as constructing a national identity per se... [so that] women's writing and involvement in colonialism was markedly different from men's...[thus] women travel writers were unable to adopt the imperialist voice with the ease which male writers did. The writing which they produced tended to be more tentative than male writing, less able to assert 'truths' of British rule without qualification. (3)

Women writers like Landon and Bird who chose to write about the East were thus highly aware of their marginalised position as authors of "colonial" subjects, one that not only exposed them to a greater level of criticism compared to their male counterparts, but also placed their personal reputations as women and thus "symbols 
of home and purity" in peril. Despite assuming the authorial role of narrator of Eastern scenes, both women are keen to emphasize how their "feminine" status as "ladies" remains uncompromised in their writings, either through self-effacement and modesty, or reinforcing domestic or social relationships.

Landon's poem "Macao," for instance, purports to be about the Chinese port, yet upon analysis, the reader discovers that the poem is not about Macao at all but instead a lamentation on the struggles of writing on a subject with which the author is completely unfamiliar, except as an "old association" with "willow-pattern plates, / That on the dresser have their station" (39-40). Indeed, Landon announces the haplessness of her situation from the very first stanza:

Good Heaven! Whatever shall I do?

I must write something for my readers:

What has become of my ideas?

Now, out upon them for seceders!

Of all the places in the world,

To fix upon a port in China;

Celestial empire, how I wish

I had been christened Celestina!

She further proclaims in despair:

I'm like a sailor sent to sea,

Sent with a "no, nothing" for his sea-hoard;

What on earth can I find to say,

Of a pagoda, or a tea-board?

No love, no murder, no description,

Their only "old association"

Is with the willow-pattern plates, 
That on the dresser have their station.

I give it up in pure despair;

But well the muse may turn refractory,

When all her inspiration is-

A Chinese Town, and an English Factory.

As an example of Orientalist poetry, "Macao" demonstrates Landon's frustration with her role as a complicit producer of such hackneyed, stereotypical imagery that her readers have come to expect from such Eastern scenery. In line with publication practices of the popular keepsake annuals of the day, in which authors wrote poems to accompany engravings pre-selected by their publishers, Landon's predicament, so publicly revealed here, illustrates her awareness and even resentment of the secondary role of her words, the need to conjure up a fitting description of this Chinese port a literal chore given her lack of expertise on the country, yet a necessity if she is to please her audience. Thus, the poem dramatizes Landon's plight as a commercially-pliant author, one who is all too aware of what sells, and yet refuses to give the audience what it wants. The irony, of course, is that Landon is paid regardless of what she writes, since by 1836 , her popularity and celebrity status would enable her to wield her authorial power, without overtly seeming to do so, as this poem indicates. Reduced to a mere "Chinese town," "Macao" the poem, nestled prettily among other Orientalist images in the pages of Fisher's Drawing Room Scrap-Book, becomes a domesticated material object for conspicuous consumption, an instance of what Evelyn O'Callaghan terms "the exotic familiarized" or "the tropics textually appropriated and made safe" (93), to be used and displayed like its factory-produced "muse", the "willow-pattern plates" of china more familiar to her genteel female audience. 
As if to impress further on her readers her struggles as a professional author made to write on demand, Landon refers yet again to the impossibility of depicting Macao, and China in general, in the poem "The Chinese Pagoda" published in the same annual. She refers to the previous task of composing "Macao" as "vexatious" and recalls how she "despaired, and knew not what to do." Ironically, her pleas to her publisher Mr. Fisher ("the simple fact-I could not write") are mercilessly ignored for "[h]ere is a second Chinese view!" In short, Landon's statements about her inability to produce appropriate descriptions of these Chinese landscapes point not only to the stereotypical Orientalist view of how one exotic foreign scene was the same as any other to the untrained and undiscerning Western eye, but also demonstrate how such images were mass-marketed to nineteenth-century British readers because they projected the powerful allure of the "East" as a place of fantasy, mystery and exoticism to which one could escape the dreariness and restraints of conventional middle-class English domestic life.

Similarly, Landon's poem "Pulo Penang” (1836) also depicts a detached view of the Orient, since like "Macao", it is nothing at all about the nineteenth-century British colony but instead illustrates her portrayal of "[a tale] of disastered love across a world-map of exotic places", with Penang serving here as one of many "fantasy locales for dark and tragic tales of the homes of England: tales telling of love's bad or betrayed faith, of women's inter-generational conflicts and blindnesses, and of the dark fatalities that seem to evolve from such circumstances" (McGann and Riess 26). Drawing upon an epigraph that depicts the beauty of the Malayan island as a "fairyland, glittering like emeralds in the golden sun, where the waving trees dip their long branches into the water," ${ }^{6}$ the poem plays out the story of the narrator who pines for his lost love, mourning how his presence on the "fairy isle" only emphasizes his 
painful separation from his beloved. Although Landon employs the voice of a male speaker in the poem, she casts the female beloved in the traditional role of passivity, a "symbol of home and purity" (to cite Mills) who patiently awaits the return of her lover to bring her "treasures from afar" and for whose sake he "sweep[s] the sea". Yet another display of Landon at work as poet for the armchair traveller, and a female one at that, the poem casts her as an author whose reputation as a spinner of tales of lost love was sufficient enough for her readership that accuracy and faithfulness to the actual locale was unessential.

\section{Bird's Asia: "Canton" and "Pinang"}

In life, as in temperament, there can perhaps be no greater study in contrasts than Landon and Bird as women authors. If Landon was disconsolate with her status as a single woman in the London social circle, and resented having to write for profit in order to support her family, Bird was singular in that her love for travel to remote places surpassed the need to write purely for profit. Indeed, as biographers like Anna Stoddard, Pat Barr, Rebecca Stefoff and John Gullick note, Bird was decidedly fit and energetic whenever abroad, yet ill, frail and depressed once at home in Edinburgh. This suggests that travelling allowed her a degree of freedom that she could never experience at home as a dutiful daughter, wife, or mother, the only socially approved roles for women in Victorian England. As she once said, "Travellers are privileged to do the most improper things with perfect propriety" (qtd. in Stoddard 115). What was initially prescribed by her doctors as a cure for her spinal ailment became a lifelong passion and obsession, one in which she indulged from the age of 18, with her first trip, to Canada, until her last, which was to Morocco, at the age of 70. She died three years later. 
Much has been written about Bird's exploits as a bold and free-spirited Victorian female traveller, an undeniable achievement that spans five decades of traversing the globe, an unusual feat even in our modern times. My focus here is on select yet representative passages from The Golden Chersonese, revolving around her travels to China (more specifically Hong Kong, or what was then termed Canton, en route to Singapore and Malaya), and her 5-week trip to the Malay States (specifically Malacca, Selangor, Penang, Taiping and Perak), narrated through the confessional yet "feminine" form of letters to her sister Henrietta from 19 January to 25 February 1879. Bird's intrepid and engaging accounts of China and Malaya in these letters, although still marked by moments of "tentativeness", stand in stark contrast to Landon's more distant and indistinct treatment of the Orient in the two poems discussed previously. As an "active participant" in colonialist discourse, Bird's position as an Orientalist author demonstrates a common experience among female travel writers, that of "their struggle with the discourses of imperialism and femininity, neither of which they could wholeheartedly adopt" (Mills 3). The Golden Chersonese is filled with such unstable textual moments, with Bird simultaneously challenging and conforming to gender stereotypes about Western female travellers in Asia.

If Landon's poem "Macao" and "The Chinese Pagoda" illustrate her implicit resentment over her publisher Fisher's influence on her literary output, then Bird's relationship with the celebrated publisher John Murray demonstrates a contrasting attitude, in that Bird refused to edit or remove potentially scandalous passages in her writings only to please her editor and her audience. Her depiction of Canton, with its place of execution described in gruesome and realistic detail, for instance, was deemed too disturbing and inappropriate by Murray; yet Bird insisted on retaining it 
as she wanted to highlight her support for the Christian missionaries in Canton, whose work she admired. Such a portrayal not only differs markedly from the prettified, pagoda-filled city of Landon's "feminine" imagination, but also demonstrates how Bird ably harnesses such an "unfeminine" depiction of an exotic setting in order to promote a worthy cause.

Bird's experiences in Malaya further emphasize her ambiguous position as a female travel writer, caught between rebelling against and conforming to gender stereotypes of the privileged European woman in Asia. Her distinctive status as a hardy, unchaperoned female traveller in Malaya is a case in point. Although constantly surrounded by men, both "native" and British, who serve as guides, translators, protectors and handlers, Bird depicts herself as the sole determinant of her adventurous journey and the shape it is to take. Indeed, she revels in such independence and freedom and displays her annoyance over being placed in a traditional position of feminine obligation and nurturance when she is made to chaperone other women. In the chapter describing her journey to Sungei Ujong with the Lieutenant-Governor of Malacca's two daughters (the Shaw sisters), for instance, she laments how they are "utterly unseasoned and inexperienced travellers, quite unfit for "roughing it"" and thus an "embarrassment" and an "encumbrance" to her, since she has been made partly responsible for their safety (157-160).

Yet such displays of self-assertion are also diluted by moments of self-doubt over her own worth and superiority as a British woman traveller in Malaya. In a passage from letter VII on Singapore, for example, she compares the beauty and grace of the Kling woman with the awkwardness of the European female form:

What thinks she, I wonder, if she thinks at all, of the pale European, paler for want of exercise and engrossing occupation, who steps out of her carriage 
in front of her, an ungraceful heap of poufs and frills, tottering painfully on high heels, in tight boots, her figure distorted into the shape of a Japanese sake bottle, every movement a struggle or a jerk, the clothing utterly unsuited to this or any climate, impeding motion, and affecting health, comfort and beauty alike? (117)

As Doris Jedamski observes, Bird's self-reflection in the passage above depicts an ironic view of herself from the imaginative perspective of the Kling woman, an instance that demonstrates how "the view on the Other is reflected in an examination of oneself' (36) and one that elides any easy assumptions of a generalized racism on Bird's part.

Such moments of introspection are however, supplanted by sweeping statements such as those that appear in Letter XVII on Penang, or "Pinang," which emphasizes the acceptance of British moral superiority among the native races: " $[\ldots]$ all these people enjoy absolute security of life and property under our flag, that they are certain of even-handed justice in our colonial courts...[...] England is "a name to conjure with," and is represented by prosperous colonies, powerful protective forces, law, liberty, and security" (237). The Penang chapter is also revealing in that it emphasizes Bird's own enviable role as a favored guest among the influential social circle of male colonial administrators, a fact that peers like Emily Innes have also resentfully pointed out in The Golden Chersonese with the Gilding Off (1885). Gullick, for instance, notes how in Penang, "Isabella was the guest of the resident High Court judge, and the guest of honour...at a formal breakfast given by the Governor" (217), and how Hugh Low, the Resident of Perak, found her an ideal guest "who never [spoke] at the wrong time" (201). In addition, Eddie Tay notes how Bird's "moving" and "sympathetic" depictions of these colonial administrators in her 
writings draw attention to colonialism as "a benevolent endeavour" (43). Thus, Bird enhances her own profile as an author by implicitly linking herself with these reputable men and in so doing, inserts herself into the colonial history of British Malaya, making her narrative even more realistic and engaging, grounded as it is in actual events and real people.

In conclusion, it is precisely such a richly diverse portrayal in Bird's account of her Malayan experience that contributes to its enduring fascination for contemporary readers, a text that offers a "tentative" yet discerning depiction of nineteenth-century British colonial life, compared to Landon's detached representations of similar views of Asia in her two Orientalist poems. While Landon's depiction of landscape and its link to empire are necessarily limited by the generic conventions of the keepsake annual, which required a brief sketch at most, compared to Bird's lengthy descriptions made possible by the form and structure of the rambling travelogue, the writings of both women illuminate their roles as figures of authority in the Victorian literary circle and demonstrate how the Orientalist text destabilizes the notion of such women writers as "marginal" voices in colonialist discourse. 
Southeast Asian Review of English, 52.1(2014/2015): 85-98.

\section{Works Cited}

Barr, Pat. A Curious Life for a Lady: The Story of Isabella Bird. London: Macmillan John Murray, 1970.

Bird, Isabella. The Golden Chersonese: A $19^{\text {th }}$-century Englishwoman's Travels in Singapore and the Malay Peninsula (1883). Singapore: Monsoon, 2010.

Blanchard, Laman. Life and Literary Remains of L.E.L., 2 vols. London: Henry Coburn, 1841.

Foster, Shirley. Across New Worlds: Nineteenth-Century Women Travelers and their Writings. New York: Harvester Wheatsheaf, 1990.

Gullick, John M., ed. Adventurous Women in South-East Asia: Six Lives. New York: Oxford, 1995.

Jedamski, Doris. Images, Self-Images and the Perception of the Other: Women Travellers in the Malay Archipelago. Hull: Center for South-East Asian Studies, 1995.

Landon, Letitia Elizabeth. Letitia Elizabeth Landon: Selected Writings. Ed. Jerome McGann and Daniel Riess. Peterborough, Ontario: Broadview, 1997.

---. “Macao" from Fisher's Drawing Room Scrap Book for 1833. Romantic Period Writings 1798-1832: An Anthology. Eds. Zachary Leader and Ian Haywood. London: Routledge, 1998.

Mills, Sara. Discourses of Difference: An analysis of women's travel writing and colonialism. London: Routledge, 1991.

O'Callaghan, Evelyn. “'A hot place, belonging to Us': The West Indies in Nineteenthcentury Travel Writing by Women.” Landscape and Empire 1770-2000. Ed. Glenn Hooper. Aldershot: Ashgate, 2005. 
Southeast Asian Review of English, 52.1(2014/2015): 85-98.

Pratt, Mary Louise. Imperial Writing: Travel Writing and Transculturation. London: Routledge, 1992.

Roberts, Emma. Views in India, China, and on the Shores of the Red Sea. London:

Fishers, 1835.

Stefoff, Rebecca. Women of the World: Women Travelers and Explorers. New York: Oxford UP, 1992.

Stephenson, Glennis. Letitia Landon: The Woman Behind L.E.L. Manchester: Manchester UP, 1995.

Stoddard, Anna M. The Life of Isabella Bird (Mrs. Bishop). New York: E.P Dutton \& Co., 1908.

Tay, Eddie. Colony, Nation, and Globalization: Not at Home in Singaporean and Malaysian Literature. Singapore: NUS Press, 2011.

Tinling, Marion. Women into the Unknown: A Sourcebook on Women Explorers and Travelers. New York: Greenwood, 1989.

\section{Notes}

${ }^{1}$ Byron's letter to Thomas Moore, prefaced in "The Corsair".

${ }^{2}$ Landon's biographer, Laman Blanchard, records her lament in the following: "It is only because I am poor, unprotected, and dependant [sic] on popularity, that I am a mark for all the gratuitous insolence and malice of idleness and ill-nature." See Blanchard, Life and Literary Remains of L.E.L.(1841), vol. 1: 54.

${ }^{3}$ Bird's own words, cited in Letter VII dated January 19, 1879, Singapore (Bird 109).

${ }^{4}$ Anna Stoddard, Life of Isabella Bird (1908).

${ }^{5}$ Landon, cited by S.C.Hall.

${ }^{6}$ From a travel book by Emma Roberts titled Views in India, China, and on the Shores of the Red Sea (1835). 